\title{
Operational performance and losses in mechanized soybean harvesting as a function of field shape
} \author{
Aline Spaggiari Alcântara', Rouverson Pereira da Silva' \\ 'Paulista State University. Jaboticabal, Brazil \\ ${ }^{2}$ Federal Technological University of Paraná, Cornélio Procópio, Brazil \\ *Corresponding author, email: andrefdamasceno@gmail.com
}

Carla Segatto Strini Paixão', André Ferreira Damasceno2*, Murilo Aparecido Voltarelli',

\begin{abstract}
Information on the capacity, operational efficiency, and performance of the harvester is very important in the management of agricultural mechanized systems, influencing decisions made with the aim of optimization. This study aimed to evaluate times, movements, and quality of mechanical soybean harvest operations in different shapes of the plots. Operational performance parameters of the harvester and variables representative of the agronomic aspects of the crop were used as indicators through statistical process control tools. Mechanized harvesting was carried out at a farm located in Uberaba, Minas Gerais, and the experimental design was completely randomized, with 18, 28, and 24 repetitions in irregular, rectangular, and trapezoidal fields, respectively. The activities of the harvester (harvest, unloading, handling, and climate charts) were monitored. The indicators of quality for harvester performance were: forward speed, engine and cylinder rotation and concave opening. The losses were determined: on the platform, internal mechanisms, total and in relation to productivity. The managerial efficiency and shunt time presented better results for the trapezoidal and rectangular section, respectively. All quality indicators evaluated were within the limits of statistical control, characterizing quality and reliability of the soybean harvesting operation.
\end{abstract}

Keywords: Exponentially weighted moving average, Glycine max (L.) Merrill, harvester machine performance, seed harvester, statistical quality control

\section{Introduction}

With the current intense mechanization and high competition in the agricultural sector, mechanized harvesting operations, which carry high added value, seek to optimize or develop techniques that maximize productivity and can reduce production costs through improvements (Linhares et al., 2012, Cassia et al., 2015). According to Santos et al. (2014), high management investments are necessary to obtain high efficiency in the harvesting process. According to Compagnon et al. (2012), recent techniques of harvest monitoring in real time help to manage the operation by extracting important information from the machinery in operation, reducing losses in the operation (Chioderoli et al., 2012).

In order to reduce the energy demand of mechanized clusters, as well as the waste inherent to the operation, the format of the plots where the culture will be implemented, has a possible significance in terms of operational efficiency. This is because in areas of greater lengths, the set will have a longer operating time in relation to the total operating time when compared to irregular areas with shorter "past" lines. Therefore, highlighting the most length/width ratio plots in which one can significantly decrease the time of maneuver and turning, as well as the discomfort of the operator in performing such operations, 
could help to avoid unnecessary dead times for the set.

According to Milan \& Fernandes (2002) and Zerbato et al. (2014), in agriculture, as well as in companies, the stabilization and improvement of the quality of operations is one of the targets for success. Thus, the decrease in variability guarantees a better quality to the process (Toledo et al., 2008; Noronha et al., 201 1; Silva et al., 2013), which can be analyzed by the statistical Process Control (CEP). The use of the CEP in mechanized harvesting operations is fundamental, because it indicates existing faults and possible options for improvements in subsequent operations (Voltarelli et al., 2015; Vidal et al., 2016). In CEP analysis, the control card tool is normally used to identify possible special causes of any stability in the process (Cassia et al., 2013; Silva et al., 2013).

Assuming that the shape of the plots can influence the operational performance of mechanized harvesting, and that such formats may influence the decision making in harvesting operations, reducing their costs, the objective of this work was to evaluate the times, movements, and quality of the operation of the mechanized harvesting of soybean in three sizes of plots. This work used parameters of operational performance of the harvester and variables representative of the agronomic aspects of the crop through statistical process control tools as indicators of quality.

\section{Material and Methods}

The experiment was carried out during March 2014, in the municipality of Conceição das Alagoas-MG, in the area of the São Sebastião Farm, located near the geodesic coordinates: Latitude: $19{ }^{\circ} 44^{\prime} 54$ "S, Longitude: $47^{\circ} 55^{\prime} 55^{\prime}$ W, with an average altitude of $801 \mathrm{~m}$. According to Peel et al. (2007), the climate of the region is considered tropical by the Köeppen-Geiger classification, with summer rains ( $A w$ ), an average temperature in the cooler month exceeding 18 ${ }^{\circ} \mathrm{C}$, absent wintery season, and a rainy summer.

Three plots with different shapes were evaluated in the same area (table 1), and plot 1 was considered irregular, the $2^{\text {nd }}$ plot was rectangular, and the $3^{\text {rd }}$ plot resembled a trapezium. The mapping of the area was completed with the aid of a GPS receiver from the brand Garmin of the model Etrex (positional precision metric). The coordinates were recorded in the UTM (Universal Transverse Mercator) planecartesian system.

Table 1. Average dimensional characteristics of the evaluated plots during mechanized harvesting of soybean

\begin{tabular}{cccc}
\hline Features & Irregular & Rectangular & Trapezoidal \\
\hline Area $(\mathrm{ha})$ & 4.41 & 8.36 & 7.19 \\
Length $(\mathrm{m})$ & 448 & 1,159 & 1,136 \\
Width $(\mathrm{m})$ & 85 & 84 & 90 \\
\hline
\end{tabular}

Sowing was performed for soybean crop implantation in November 2013, with spacing of $0.50 \mathrm{~m}$ between lines and 21 to 22 seeds $\mathrm{m}^{-1}$, totaling sowing densities of approximately 430,000 seeds $\mathrm{ha}^{-1}$, using the BMX Turbo RR variety Developed by Brasmax (BMX), with a germination rate of $99 \%$.

For the mechanized harvesting of soybean, a harvester from the brand Massey Ferguson, model MF 5650 Advanced, year 2010 was used, which had completed approximately $700 \mathrm{~h}$ of work.

The harvester had an AGCO Sisu power six-cylinder engine with nominal power of $130 \mathrm{KW}$ (175 hp). The engine was equipped with a 5.00 $\mathrm{m}$ wide cutting platform with automatic height control, had a tangential-type track system, separation between sack-straw and bulk tank, and a capacity of $5500 \mathrm{~L}$. The harvester worked with average rotor rotation of $2565 \mathrm{rpm}$, average cylinder rotation of $1100 \mathrm{rpm}$, average opening of the concave of $33 \mathrm{~mm}$, and displacement speed of $5,0 \mathrm{~km} \mathrm{~h}^{-1}$.

The model G600, from the Gehaka AGRI brand, was used in the experiment to measure the temperature and the water content of the grains. This device performed the measurements in a few seconds, without destroying the sample, using batteries or plugged into the mains, and has a self-calibration system that readjusts the equipment to each measure.

The harvester's performance assessments and harvest parameters were performed according to the quality statistical 
control methodology. They were determined at a fixed time interval (15 minutes) between the assessments (Montgomery, 2009) and were measured during the day in the period from 10 to 18 hours. There were 18,28 , and 24 repetitions for plots 1, 2 and 3, respectively. The treatments were established from the shapes of the plots, without the need to exchange the harvester operator during the harvest, thereby providing better control conditions for the experiment.

Data on the monitoring of harvester activities (table 2) was collected with a field booklet, clipboard, and stopwatch. One person was assigned to accompany the automotive harvester from the beginning to the end of the operation, noting the activity, which was done at regular intervals of 10 minutes until the harvest was finished in each field evaluated.

Table 2. Division of activities in soybean harvesting.

\begin{tabular}{ll}
\hline \multicolumn{1}{c}{ Activity } & \multicolumn{1}{c}{ Description } \\
\hline 1. Total Harvest Time & $\begin{array}{l}\text { Time in which the machine was intended to carry out the mechanized } \\
\text { harvesting operation itself, including the maneuver times }\end{array}$ \\
\hline 2. Grain Discharge & $\begin{array}{l}\text { Time required for the machine to move to the unloading points and } \\
\text { perform the grain discharge, until its return to harvesting activity }\end{array}$ \\
\hline 3. Problems in the Harvester & $\begin{array}{l}\text { Time required for resolution of unforeseen issues, such as repairs and/or } \\
\text { infilling }\end{array}$ \\
\hline 4. Climatic Stoppages & $\begin{array}{l}\text { Dedicated time due to climatic adversities, until the return of the } \\
\text { Harvesting operation on the plot }\end{array}$ \\
\hline 5. Maneuver Time & $\begin{array}{l}\text { Dedicated time stops due to the bedside maneuvers performed by the } \\
\text { harvester in each plot }\end{array}$ \\
\hline
\end{tabular}

Based on the data collected, the variables related to Asabe standards EP 496.3 (2011) and Mialhe (1974) were calculated.

The effective field capacity was calculated according to the methodology described by Mialhe (1974) (EQ. 1):

$$
\mathrm{CCE}=\frac{V \times L}{10}
$$

\section{Where:}

CCE: Effective field capacity $\left(\mathrm{ha} \mathrm{h}^{-1}\right)$;

$\mathrm{V}$ : Speed $\left(\mathrm{km} \mathrm{h}^{-1}\right)$;

L: Platform width (m);

The operational field capacity was calculated according to the methodology described by Mialhe (1996) (EQ. 2):

$$
\mathrm{CCO}=\frac{V \times L \times E f}{10}
$$

Where:

BCC: Operational field capacity (ha $\mathrm{h}^{\mathrm{l}}$ );

$\mathrm{V}$ : Speed $\left(\mathrm{km} \mathrm{h}^{-1}\right)$;

$\mathrm{L}$ : Platform width (m);

EF: Harvester efficiency.

To calculate the Harvesting efficiency

(Ecol), Field efficiency (Ec) and Efficiency management (Eg) the methodology described by the norms of Asabe EP 496.3 (2011) was used, and can be seen in eq. 3, eq. 4, and eq. 5:

$$
E \operatorname{col}(\%)=\left\{\frac{T c}{T c+T d+T p+T m}\right\} \times 100
$$

Where:

Ecol: harvesting efficiency (\%);

Tc: Harvest Operation Time (h);

Td: Discharge operation time (h);

Tp: Harvester time in maintenance.

$$
E C(\%)=\left\{\frac{C C O}{C C E}\right\} \times 100
$$

Where:

Ec: field efficiency (\%);

CcE: Effective field capacity (ha $\left.\mathrm{h}^{\prime}\right)$;

$\mathrm{CcO}$ : Operational field capacity $\left(\right.$ ha $\left.^{-1}\right)$.

$E g(\%)=\left\{\frac{T c+T d}{T c+T d+T p+T m}\right\} \times 100$

Where:

Eg: Efficiency Management (\%);

Tc: Harvest Operation Time (h);

Td: Discharge operation time (h);

Tp: Harvester Time in Maintenance (h).

The harvesting operation time (TC), Discharge time (Td), Maintenance Time (TP), and time of Maneuver (TM) were calculated according to the methodology described by Mialhe (1996) according to eq. 6, eq. 7, eq. 8, and eq. 9, respectively. 


$$
T c(\%)=\left\{\frac{T c}{T c+T d+T p+T m}\right\} \times 100
$$

Where:

Tc: Harvest operation time (\%);

Tc: Harvest Operation Time (h);

Td: Discharge operation time (h);

Tp: Harvester Time in Maintenance (h).

$$
\operatorname{Td}(\%)=\left\{\frac{T d}{T c+T d+T p}\right\} \times 100
$$

Where:

Td (\%): Discharge operation time (\%);

Tc: Harvest Operation Time (h);

Td: Discharge operation time (h);

Tp: Harvester Time in Maintenance (h).

$T p(\%)=\left\{\frac{T p}{T c+T d+T p+T m}\right\} \times 100$

Where:

Tp: Harvester time in maintenance (\%);

TC: Harvest Operation Time (h);

TD: Discharge operation time (h);

Tp: Harvester Time in Maintenance (h).

$\operatorname{Tm}(\%)=\left\{\frac{T m}{T c+T d+T p+T m}\right\} \times 100$

Where:

Et (\%): Time efficiency (\%);

TT: Total harvest time of the whole plot;

TC: Harvest Operation Time (h);

TD: Discharge operation time (h);

Tp: Time of the harvester in maintenance (h);

Tm: Time of Maneuver (h).

Also, using the methodology described by Mialhe (1974), the length/width (C/L) ratio of each plot (eq. 10) was determined.

$$
C / L=\frac{C}{L}
$$

Where:

C/L: Length/width ratio of the plots;

C: Average of the lengths for each plot (m);

$\mathrm{L}$ : Average widths for each plot (m)

The methodology for determination of losses was adapted from Ferreira et al. (2007), in which three circular frames were used with areas of $0.33 \mathrm{~m}^{2}$, sealed with a black plastic screen resembling sieves, which together totaled an area of approximately $1.00 \mathrm{~m}^{2}$.

The hoops were released shortly after the harvester platform passed pre-determined points, so that two hoops were arranged outside the tracing of the front wheels of the harvester (left and right) and a third was released between the wheelset (medium). All grains and pods present in the hoops were collected after the harvester passed.

The losses in mechanized soybean harvesting were defined as follows: The grains and pods found below the sieve were considered as losses of the platform ladded to the natural losses); The losses of the internal mechanisms were represented by the grains and pods found on the top of the sieve; And finally, the total losses were calculated summing the losses of the platform and the internal mechanisms.

For each plot, total losses in relation to yield were calculated based on the average yield and were measured by the quantity of soybean trucks delivered and weighed using a precision balance of grain processing unit. The average yield for each plot was estimated as: $2,480 \mathrm{~kg} \mathrm{ha}^{-1}$ for the irregular plot, $2,600 \mathrm{~kg} \mathrm{ha}^{-1}$ for the rectangular plot, and $2,480 \mathrm{~kg} \mathrm{ha}^{-1}$ for the trapezoidal plot.

Data analysis was performed through statistical process control using the exponentially weighted moving average charts tool (EWMA), also known as advanced control charts. These are enhancements of the Shewhart charts developed for specific situations, which aim to minimize the occurrence of points outside the control limits (false alarms) and non-visible alarms (Samohyl, 2009), owing to their greater rigorousness of analysis.

The exponentially weighted moving average (EWMA) is defined according to Montgomery (2009) and is seen in equation 11:

$$
z_{i}=\lambda \cdot \sum_{j=0}^{i-1}(1-\lambda)^{j} \cdot x_{i-j}+(1-\lambda)^{i} \cdot z_{0}
$$

Where:

$\mathrm{Z}_{\mathrm{i}}$ : Weighted moving average value; $\mathrm{X}_{\mathrm{i}}$ :Measured characteristic value; $Z_{0}$ :Average target of the process; $\lambda$ : Analysis stiffness factor;

i:1, 2, 3, (samples).

The upper and lower limits of control of the cards that constitute the exponentially weighted moving average (EWMA) were 
calculated according to equations 12 and 13 , respectively:

$$
\begin{aligned}
& \text { LSC }=\mu+L . \sigma \cdot \sqrt{\frac{1}{(2-\lambda)} \cdot\left[1-(1-\lambda)^{2}\right]} \\
& \text { LC= }=\mu-L . \sigma \cdot \sqrt{\frac{1}{(2-\lambda)} \cdot\left[1-(1-\lambda)^{2}\right]}
\end{aligned}
$$

Where:

LSC: Upper control limit;

LIC: Lower control limit;

$\mu$ :General average;

L: Width of the range between the average and the limit;

\section{$\sigma:$ Standard deviation;}

$\lambda$ : Analysis stiffness factor;

i: 1, 2, 3, (samples).

The control charts for the exponentially weighted moving average were calculated using the width of the range between the mean and the control limits, as the stiffness factor of the analysis was chosen as $\lambda=0.4$ based on the sample number (three). This value was chosen by virtue of Montgomery's recommendation (2009), in which the author recommends using $\lambda=0.4$, when the band width is used with a value of 3 (three). It is also noteworthy that this tool does not require the normal distribution of probability of data used in the monitoring of processes.

\section{Results and Discussion}

\section{Operational Performance}

The effective and operational field capacities were higher for the trapezoidal plot when compared to the other plots (table 3). This was because of the higher average working speed of the harvester and the field and harvest efficiencies, as the format of the plot and the culture itself favor such conditions.

On the other hand, the harvesting efficiency for the $1^{\text {st }}, 2^{\text {nd }}$, and $3^{\text {rd }}$ plots were 71.42 , 70.10 , and $72.70 \%$, respectively. It is noted that the irregularly shaped plot 1 influenced the amount of time taken for grain discharge (18.57\%) during the operation of soybean harvest, as this value was higher compared to the other plots.

For field efficiency (EC), plot 2 showed higher values (82\%), followed by plots $3(57.65 \%)$ and 1 (54\%). This result can be explained by the fact that Ec indicates how efficient the system is in terms of maneuvering and unloading times. Therefore, it is verified that the plot 1 (irregular shape) showed a lower field efficiency, also evidenced by the variables Td (discharge time) and Tm (time of maneuver), which presented high values in this plot, thereby decreasing the time intended for harvesting (TC).

According to Araldi et al. (2013), the average values found for field efficiencies and time in mechanized harvesting of irrigated rice were $65.2 \%$ and $75.7 \%$, respectively. On the other hand, the present study showed lower field efficiency values for the irregular and trapezoidal plots, a characteristic that limited the operational performance of the harvester and soybean harvesting.

The managerial efficiency (Eg) indicates the influence of the time stopped on the harvesting operation, in which the best result was seen for plot 3 (92.72\%) followed by plot 1 (90\%) and plot 2 (71 5\%). At the same time, these results are mainly because of the time for resolution of

Table 3. Analysis of the times, movements, and efficiency of the mechanized harvesting of soybeans in different

\begin{tabular}{|c|c|c|c|}
\hline \multirow{2}{*}{ Variables } & \multicolumn{3}{|c|}{ Plots } \\
\hline & Irregular (1)* & Rectangular (2) & Trapezoidal (3) \\
\hline CCE $\left(\right.$ ha $^{-1}$ ) & $2.00 \mathrm{C}$ & $2.25 \mathrm{~B}$ & $2.50 \mathrm{~A}$ \\
\hline $\operatorname{Bcc}\left(\mathrm{ha} \mathrm{h}^{-1}\right)$ & $1.43 \mathrm{C}$ & $1.57 \mathrm{~B}$ & $1.81 \mathrm{~A}$ \\
\hline Ecol $(\%)$ & 71.42 & 70.10 & 72.70 \\
\hline Ec $(\%)$ & 54.00 & 82.00 & 57.65 \\
\hline Eg (\%) & 90.00 & 71.50 & 92.72 \\
\hline Tc (\%) & 49.15 & 58.78 & 36.38 \\
\hline Td (\%) & 18.57 & 11.90 & 17.20 \\
\hline $\mathrm{Tp}(\%)$ & 10.00 & 17.90 & 9.90 \\
\hline $\operatorname{Tm}(\%)$ & 22.28 & 11.42 & 36.52 \\
\hline$C / L$ & 5.26 & 7.04 & 6.47 \\
\hline
\end{tabular}
plots. 
unforeseen issues, such as repairs and/or infilling /maintenance (TP), since plot 2 (rectangular), although it gave the best results in the other variables (Tc, Td, and Tm), had a very high stop/ maintenance time (17.9\%), making its Eg value the worst found among the evaluated plots.

When comparing the three plots in relation to the time of maneuver (Tm), it was observed that plot 3 presented the highest value, with a $\mathrm{Tm}$ value of $36.52 \%$. The possible explanation for this fact is that a vinasse channel that was situated at the top of the plot made it difficult to shift the harvester, as well as to maneuver it at the end of the length of the plot. Moreover, the geometry of the terrain in this field caused the more continuous displacement of the harvester, increasing the need for maneuvers and, consequently, the time of maneuver.
In this condition, it can be observed that the rectangular shaped plot made maneuvers easier in relation to other plots. These results can be explained by the high length/width ratio (C/L $=7,04)$ in the rectangular plot, which decreased the number of maneuvers per harvested area.

\section{Statistical Process Control}

Observing the control charts, the water content of the soybean grains was stable during the operation in the irregular plot, with all data points within the lower and upper limits of control (Figure 1). Contrastingly, water content was unstable in the rectangular and trapezoidal plots, presenting points that extrapolate the established control limits, which may be related to the spatial variability of the crop (Carvalho and Novembre, 2012).

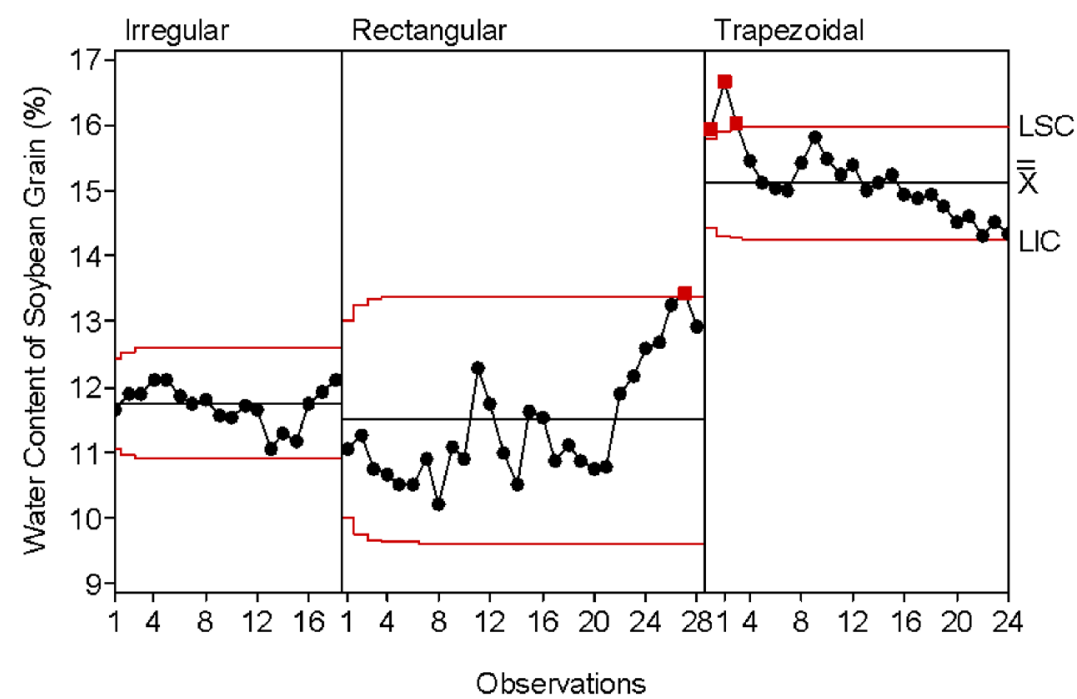

Figure 1. Control charts for the water content of soybean grains during mechanized harvesting. LSC: Upper control limit. LIC: Lower control limit. $\overline{\mathrm{X}}$ : Exponentially weighted moving average of sample values.

It was observed that the smallest variation in this quality indicator occurred in the irregular plot, with most sampling points concentrating around a single value. According to Costa and Tavares (1995), the values obtained for the irregular and rectangular plots are within the range of water content considered viable for mechanical harvesting (13\%), in terms of both physical losses and damage.

In contrast, the largest variation was observed in the trapezoidal plot, because in the night preceding the harvesting of the trapezoidal plot, there was an occurrence of rain, which resulted in an increase in the water content of the harvested grains. This consequently may have influenced the amount of losses, as high humidity may result in both physical losses and latent mechanical damage, according to Costa and Tavares (1995). However, according to França Neto et al. (2007), mechanized harvesting can be performed with higher water content (18\%) provided that adjustments are made to the track systems and there is sufficient artificial drying structure.

It is also noted that in the rectangular plot there was an increase in the water content in 
the grains (up to 13.5\%) from observation 20 to 27 , a situation that can be explained by the harvest being performed after 18:00 hours. This fact differs from that observed by Marcondes et al. (2010), which reported that seeds of the cultivar BRS 184, harvested at the time of 10 hours presented water content higher than $15 \%$ while those harvested at the time of 18 hours had a water content below $12 \%$.

It is also noteworthy that by associating the standard values of randomness together with this type of control chart, one can only verify the occurrence of natural causes in both analyses, a fact that can contribute to a better analysis of the process, as well to assist in the best decisionmaking during the process.

Figure 2 shows the behavior of soybean grain temperature during the harvest of the three plots evaluated. It was observed that this variable was unstable during the operation for all the plots, showing values outside the lower limits and superior control. Such instability may be associated with non-randomness patterns verified during harvesting: clustering for all the evaluated plots and trend for the trapezoidal.

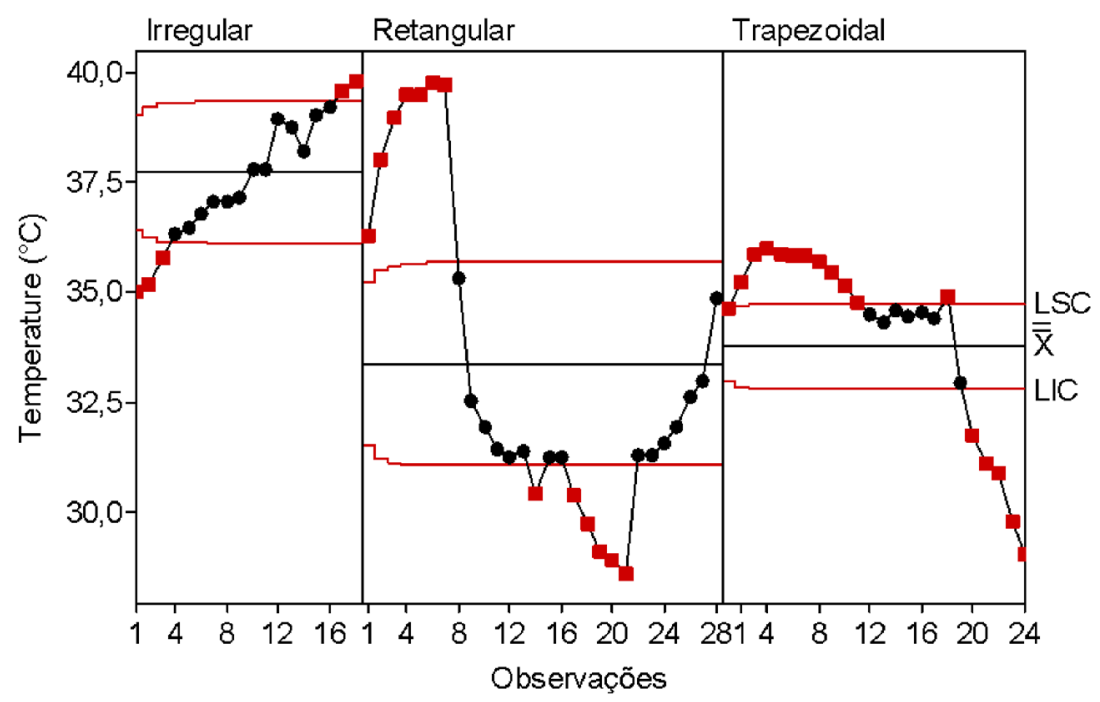

Figure 2. Control charts for soybean grain temperature during mechanized harvesting. LSC:

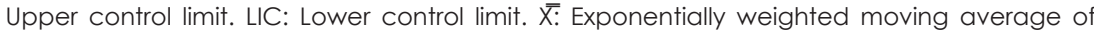
sample values.

It was noted that the smallest variation and the highest values for this quality indicator occurred for the irregularly shaped field, because the grains had low water content resulting in higher temperatures. Holtz et al. (2013) identified an inverse correlation between the water content of grains and the temperature of grains, meaning that when the water content decreases, the temperature increases. These variables are significantly correlated with the total losses. The inverse situation was observed in the trapezoidal plot in which the temperatures were lower because of the occurrence of rain prior to harvesting.

Figure 3 shows that losses on the platform were stable during the harvesting operation in the irregular plot, presenting a non-random grouping pattern. In the rectangular plot, all the observations were within the lower limits and superior control. In the trapezoidal plot instability was observed, with only one point outside the established control limits, but it was very close to these limits.

It was perceived that the values for this variable (Figure 3) are above the recommended values, given that during the entire experiment, as previously mentioned, there were problems in the regulation of the platform. This issue mainly occurred in the rectangular plot, in which maintenance of the harvester was necessary. This fact can be seen in the data as the most expressive values and greatest variation of this type of loss were observed in the rectangular plot. However, this situation is consistent with Schanoski et al. (2011), where it was observed that most of the losses occur in the cutting platform.

The losses in the internal mechanisms were unstable during the mechanized harvesting 
of soybean for the three plot formats evaluated (irregular, rectangular, and trapezoidal). For this variable, a similar pattern is noted between the plots, which exhibited only one point outside the upper and lower limit established (Figure 4). This situation was also observed by Chioderoli et al. (2012), who reported that the mean grain loss in the trail system was unstable, and that the process was out of control but within the acceptable patterns of losses for soybean crop.

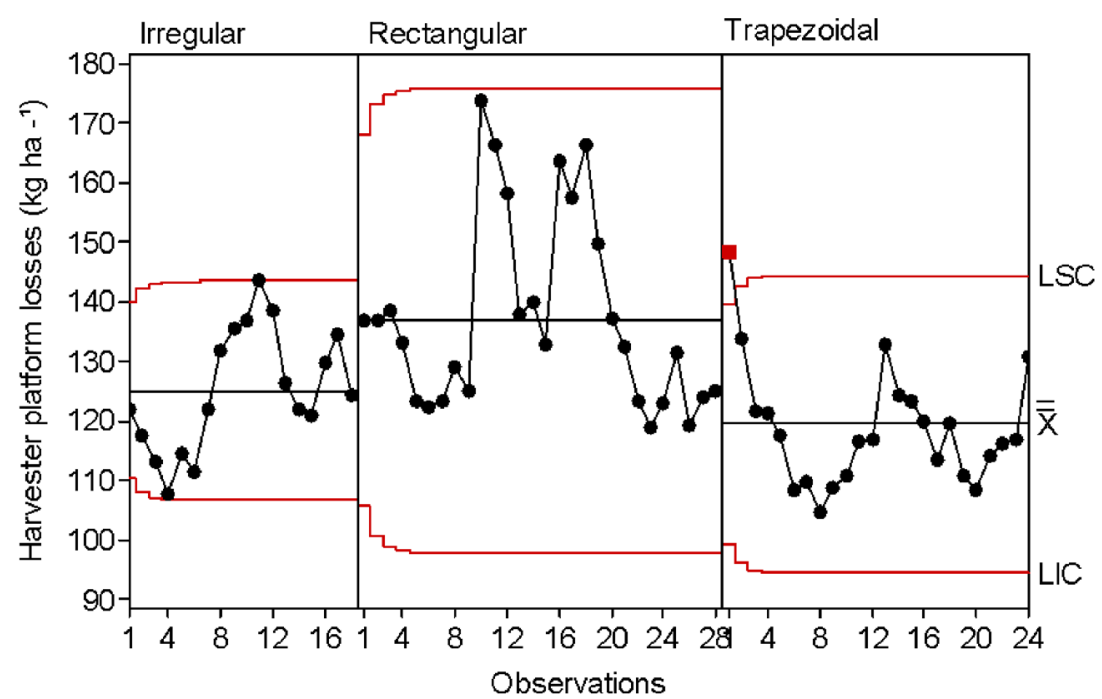

Figure 3. Control charts for losses on the harvester platform during mechanized soybean harvesting. $\overline{\mathrm{X}}$ : Exponentially weighted moving average of sample values.

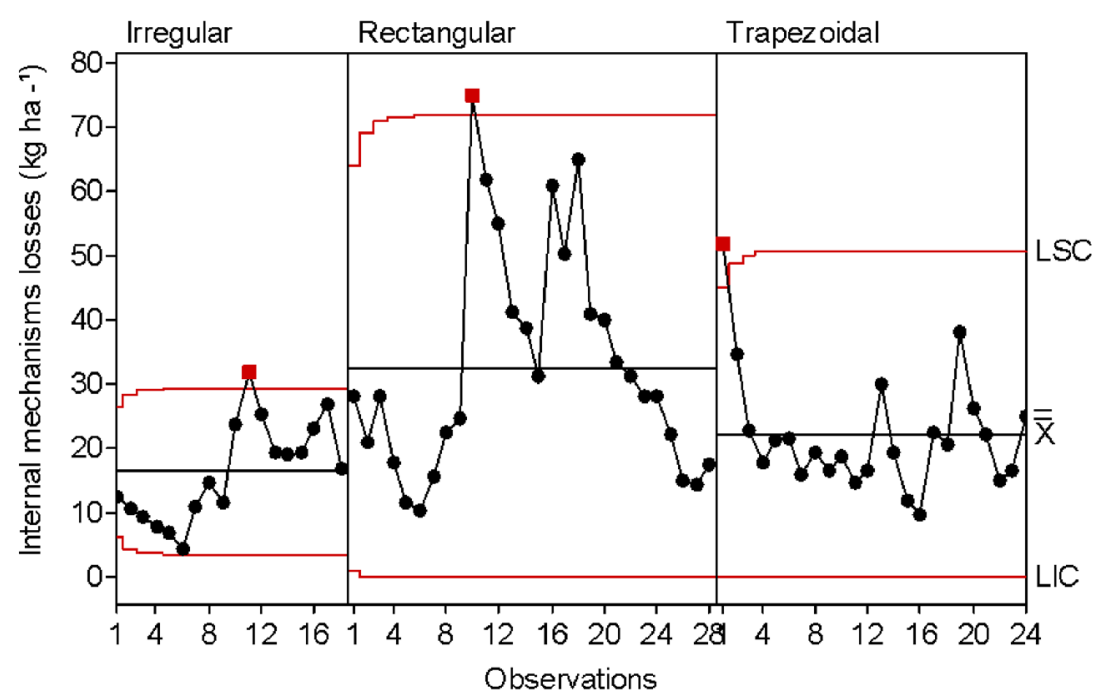

Figure 4. Control charts for losses of the internal mechanisms of the harvester during the mechanized harvesting of soybeans. LSC: Upper control limit. LIC: Lower control limit. $\overline{\mathrm{X}}$ Exponentially weighted moving average of sample values.

In the irregular field, a lower variation in the values was observed compared with the other plots evaluated, and this was verified by the smallest amplitude between the control limits. Thus, due to the use of more adequate adjustments, it obtained higher efficiencies in the track system, evidenced by the lower losses of the platform (Marcondes et al., 2010; Chioderoli et al., 2012).

This observation can be explained by the water content of the grains at the time of the harvesting operation, as the grains were drier and the regulations used by the operator were correct, which differed from the results in the rectangular plot, which showed a pattern of oscillation, and in the trapezoidal plot, in which the grains had higher water content and hinted the harvesting.

According to Tabile et al. (2008), which studied the rotation of the Trekker cylinder, 
associating them with the water content of the grains, the losses in the internal mechanisms were higher than the losses in the platform, a situation that differs from the present study, in which the losses in the platform were higher.

Thus, special occurrences in agricultural operations may be linked to several factors that generate variability, called "the $6 \mathrm{M}$ 's". These factors include labor, environment, machine, methods, measurement, and raw materials. In this case, one can cite: incorrect harvester regulation, operator experience, differences in soil conditions, variations in displacement speed, and pest attack as possible causes of variation, among other factors. Ormond et al. (2018) cites as special causes the harvesting, the interaction between the machine and environmental factors. However, according to Hessler, Camargo, and Dorion (2009), even in a well-planned and carefully monitored productive process there will always be natural variation, due to common causes (random), and the stability of the same is observed.

Total losses were stable during harvesting in the irregular plot, with all the points within the lower and upper limits of control (Figure 5), and within the national average that, according to Campos et al. (2005), is $120.0 \mathrm{~kg} \mathrm{ha-1}$. Meanwhile, the rectangular and trapezoidal plots were unstable, with points that extrapolate the calculated control limits. It is also noteworthy that, for all the plots, for this indicator of quality, there was only the presence of random order patterns.

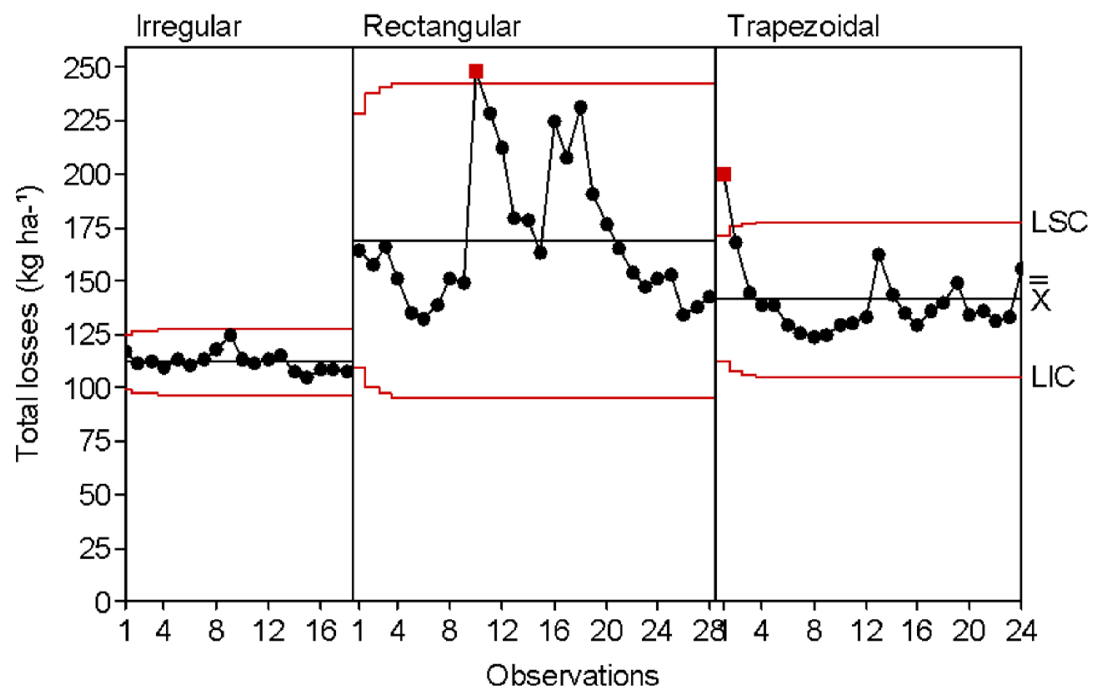

Figure 5. Control charts for total losses of soybean grains during mechanized harvesting. LSC: Upper control limit. LIC: Lower control limit. $\overline{\mathrm{X}}$ : Exponentially weighted moving average of sample values.

The smallest variation in this quality indicator occurred in the irregular plot, with most sampling points concentrating around a single value, which reflected in control limits close to the mean. This is the inverse situation to what occurred in the rectangular and trapezoidal plots.

For all the plots, the total losses presented higher values than the optimum. This performance can be attributed to the problems that occurred during the whole harvest, mainly by factors involving machine and labor, like situations in which the harvester operated with inadequate adjustments and presented problems in the cutting platform, mainly for the rectangular plot.
Magalhães et al. (2009) observed that the losses in the cleaning system $\left(56.16 \mathrm{~kg} \mathrm{ha}^{-1}\right)$ contributed more to the total losses $\left(88.62 \mathrm{~kg} \mathrm{ha}^{-1}\right)$ than the losses on the platform $\left(32.46 \mathrm{~kg} \mathrm{ha}^{-1}\right)$. This contradicts the results of this study, in which the losses on the platform contributed largely to the total losses. Thus, it can be concluded that the regulation, the training of the operator, and the conservation status of the harvester are important to minimize losses in the mechanized harvesting of soybean, this fact is also corroborated by Voltarelli et al. (2017).

Losses in relation to productivity (P\%) showed instability in the three plots evaluated, with at least one point outside the control limits 
(Figure 6) per plot. It is also noteworthy that the greatest variability in the harvesting operation occurred in the rectangular plot, and the probable explanation is the losses on the cutting platform, as previously mentioned.

It was also observed that the irregular plot showed a non-random grouping pattern, and when this behavior is viewed in relation to the losses of the platform, it can be seen that they are equal. This situation may have resulted from losses on the platform directly influencing the clustering pattern.

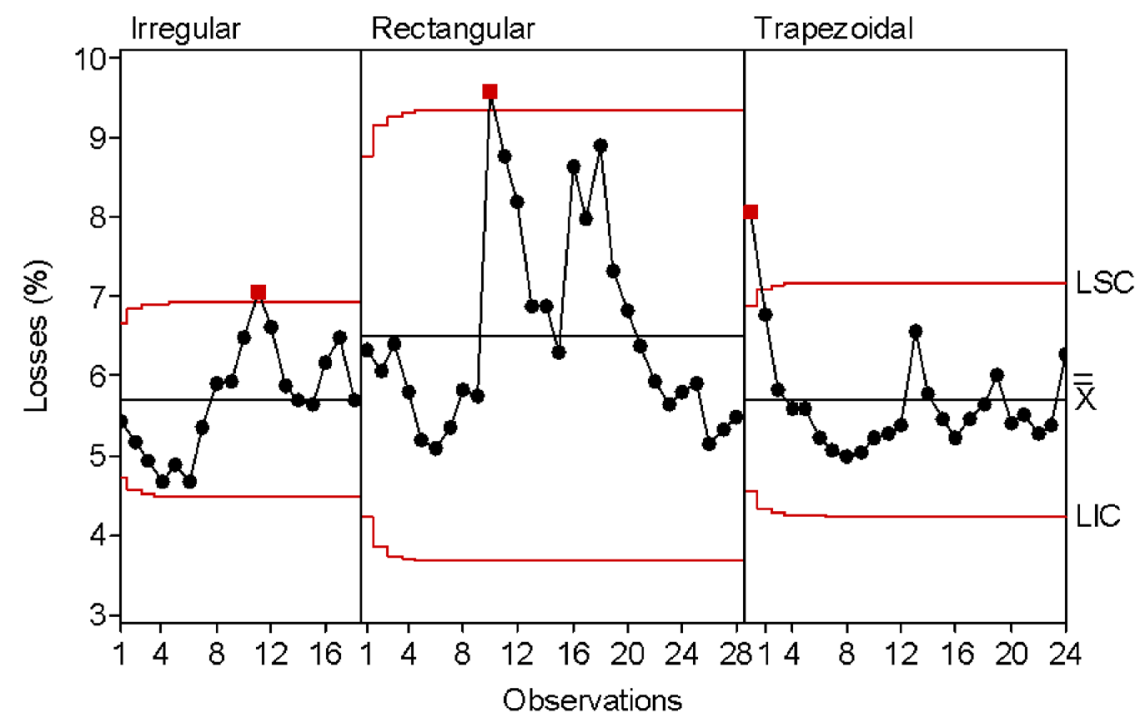

Figure 6. Control charts for total losses in relation to yield (\%) of the harvester during the mechanized harvesting of soybean. LSC: Upper control limit. LIC: Lower control limit. $\overline{\mathrm{X}}$ Exponentially weighted moving average of sample values.

\section{Conclusions}

The shape of the plots affects the efficiency of time and movements of the harvester and the quality of the operation of the mechanized harvesting of soybeans.

The irregular and trapezoidal plot shape had a lower field efficiency value (EC) compared to the rectangular plot.

For all types of losses, the rectangular plot presented the highest values.

All quality indicators evaluated were within the limits of statistical control, characterizing quality and reliability of the soybean harvesting operation.

\section{References}

Araldi, P.F., Schlosser, G.F., Frantz, U.G., Ribas, R.L., Santos, P. M. 2013. Eficiência operacional na colheita mecanizada em lavouras de arroz irrigado. Revista Ciência Rural, 43: 445-451.

ASABE (AMERICAN SOCIETY OF AGRICULTURAL BIOLOGICAL ENGINEERS). 2011 ASABE EP 496 JUN11: Agricultural machinery management data. In: ASABE Standards 2011: standards engineering practices data. St. Joseph. 6 p.

Campos, M. A. O.; Silva, R. P. da; Carvalho Filho,
A.; Mesquita, H. C. B.; Zabani, S. 2005. Perdas na colheita mecanizada de soja no estado de Minas Gerais. Revista de Engenharia Agrícola, 25: 207-213.

Cassia, M.T., Silva, R.P., Chioderolli, C.A., Noronha, R.H.F., Santos, E.P. 2013. Quality of mechanized coffee harvesting in circular planting system. Ciência Rural, 43: 28-34.

Cassia, M.T., Voltarelli, M.A., Silva, R.P., Zerbato, C., Lima, P.H. 2015. Monitoramento da operação de colheita mecanizada de sementes de soja. Revista Brasileira de Engenharia Agrícola e Ambiental, 19: 1209-1214.

Carvalho, T. C.; Novembre, A. D. L. C. 2012. Qualidade de sementes de soja colhidas de forma manual e mecânica com diferentes teores de água. Semina: Ciências Agrárias, 33: 155-166.

Chioderoli, C.A., Silva, R.P., Noronha, R.H.F., Cassia, M.T., Santos, E.P. 2012. Perdas de grãos e distribuição de palha na colheita mecanizada de soja. Bragantia, 71: 112-121.

Compagnon, A. M., Silva, R. P., Cassia, M. T., Graat, D., Voltarelli, M. A. 2012. Comparação entre métodos de perdas na colheita mecanizada de soja. Scientia agropecuária, 3: 215-223.

Costa, N.P.; Tavares, L.C.V. 1995. Fatores responsáveis pelos elevados percentuais de 
perdas de grãos durante a colheita mecânica de soja. Informativo ABRATES, Brasília, 5(1): 17-25.

França Neto, J. B.; Krzyzanowski, F. C.; Pádua G. P. De; Costa; N. P. Da, Henning, A.A. 2007. Tecnologia da produção de semente de soja de alta qualidade. Londrina: Embrapa Soja, p.12 (Circular Técnica n. 40 - Série Sementes).

Hessler, C.V.; Camargo, M.E.; Dorion, E. Application control charts for analysis of quality in industrial painting. In: INTERNACIONAL CONFERENCE ON COMPUTERS \& INDUSTRIAL ENGINEERING 39., 2009, Troyes: Proceedings..., Troyes: IEEE Xplore, 2009. p. 1330-1334.

Holtz, V., dos Reis, E. F. (2013). Perdas na colheita mecanizada de soja: uma análise quantitativa e qualitativa. Revista Ceres, 60(3): 347-353.

Linhares, M., Sette Júnior, C.R., Campos, F., Yamaji, F.M. 2012. Eficiência e desempenho operacional de máquinas harvester e forwarder na colheita florestal. Pesquisa Agropecuária Tropical, 42: 212-219.

Magalhães, S.C., Oliveira, B.C., Toledo, A., Tabile, R.A., Silva, R.P. 2009. Perdas quantitativas na colheita mecanizada de soja em diferentes condições operacionais de duas colhedoras. Revista Bioscience Journal, 25: 43-48.

Marcondes, M.C., Miglioranza, E., Fonseca, I.C.B. 2010. Qualidade de sementes de soja em função do horário de colheita e do sistema de trilha de fluxo radial e axial. Engenharia Agrícola, 30: 315321.

Mialhe, L. G. 1974. Manual de mecanização agrícola. Agronomica Ceres, São Paulo, Brasil. $301 \mathrm{p}$.

Mialhe, L. G. 1996. Máquinas agrícolas: ensaios e certificações. CNPq-PADCT/TIB, Piracicaba, Brasil. 600 - 650 p.

Milan, M., Fernandes, R.A.T. 2002. Qualidade das operações de preparo de solo por controle estatístico de processo. Scientia Agrícola, 59: $261-266$.

Montgomery, D. C. 2009. Design and analysis of experiments. Wiley, Hoboken, United States of America. 179-268 p.

Noronha, R.H.F., Silva, R. P., Chioderoli, C.A., Santos, E.P., Cassia, M.T. 2011 . Controle estatístico aplicado ao processo de colheita mecanizada diurna e noturna de cana-de-açúcar. Bragantia, 70: 931-938.

Peel, M.C., Finlayson, B.L., Mcmahon, T.A. 2007. Updated world map of the Koppen-Geiger climate classification. Hydrology and Earth System Sciences, 4: 439-473.
Ormond, A. T., Dos Santos, A. F., Alcântara, A. S., Zerbato, C., \& Furlani, C. E. 2018. Tillage interference in the quality of peanut mechanized harvest. Engenharia Agrícola, 38(2): 251-259.

Samohyl, R. W. 2009. Estatística aplicada. In: (Ed.). Controle estatístico de qualidade. Elsevier, Rio de Janeiro, Brasil. 7-75 p.

Santos, N.B., Cavalcante, D.S., Fernandes, H.C., Gadanha Junior, C.D. 2014. Simulação da eficiência de campo da colheita mecanizada de cana-de-açúcar (Saccharum spp.). Energia na Agricultura, 29: 09-13.

Schanoski, R., Righi, E. Z., Werner, V. 2011 . Perdas na colheita mecanizada de soja (Glycine max) no município de Maripá-PR. Revista Brasileira de Engenharia Agrícola e Ambiental-Agriambi, 15(11).

Silva, R.P., Cassia, M.T., Voltarelli, M.A., Compagnon, A.M., Furlani, C.E.A. 2013. Qualidade da colheita mecanizada de feijão (Phaseolus vulgaris) em dois sistemas de preparo do solo. Revista Ciência Agronômica, 44: 61-69.

Tabile, A. R, Toledo, A., Silva, R. P., Furlani, C. E. A., Grotta, D. C. C., Cortez, J. W. 2008. Perdas na colheita de milho em função da rotação do cilindro trilhador e umidade dos grãos. Scientia Agrária, Curitiba, 9(4): 505-510.

Toledo, A., Tabile, R.A., Silva, R.P., Furlani, C.E.A., Magalhães, S.C., Costa, B.O. 2008 Caracterização das perdas e distribuição de cobertura vegetal em colheita mecanizada de soja. Engenharia Agrícola, 28: 710-719.

Vidal, D.A., Voltarelli, M.A., Silva, R.P., Cassia, M.T., Tavares, T.O. 2016. Indicadores de qualidade para sistemas de preparo do solo no transplantio de citros. Comunicata Scientiae, 7:343-353.

Voltarelli, M.A., Silva, R.P., Cassia, M.T., Ortiz, D.F., Torres, L.S. 2015. Qualidade do corte basal de cana-de-açúcar utilizando-se de três modelos de facas. Engenharia Agrícola, 35: 528-541.

Voltarelli, M. A., Silva, R. P. D., Cassia, M. T., Daloia, J. G. M., \& Paixão, C. S. S. (2017). Quality of base cutting in sugarcane using knives of different angles and coatings. Revista Ciência Agronômica, 48(3): 438-447.

Zerbato, C., Furlani, C.E.A., Voltarelli, M.A., Bertonha, R.S., Silva, R.P. 2014. Quality control to seeding systems and densities in peanut crop. Australian Journal of Crop Science, 6: 992-998. 